\title{
Mutualistic Symbiosis between Arbuscular Visicular Mycorrhizal Fungi with Cassava Plant (Manihot esculenta Crantz)
}

\author{
Muchdar Soedarjo* \\ Indonesian Legumes and Tuber Crops Research Institute, P.O. Box 66, Malang, Indonesia \\ 65101.
}

*Corresponding Author: Muchdar Soedarjo, Indonesian Legumes and Tuber Crops Research Institute, P.O. Box 66, Malang, Indonesia 65101. Email: muchdar.soedarjo62@gmail.com

\begin{abstract}
Fertilization in cassava is necessary to improve soil nutrient availability, growth and tuber yield. However, cassava farmers, especially in sub-optimal (potential) land generally fertilize their plants with NPK fertilizer less than the recommended dosage. Therefore, nutrients from other sources are needed. This paper explains that some nutrients, especially P, could be substituted through mycorrhizal symbiosis. In return, mycorrhizal fungus obtains the energy from cassava as a host. Thus, Such an association is beneficial for both parties, the plant and its symbiont. This fungus forms vesicular and arbuscular structures in cortical tissues of the plant root and then is known as vascular-arbuscular mycorrhizae (VAM). The degree of growth and tuber yield Improvement due to mycorrhizae is determined by the genera and species of the VAM. The genetics of cassava also influence significantly the effectiveness of VAM. In addition to the improvement of nutrient absorption, VAM also enhances tolerance of cassava to drought, saline and some root diseases. Root disease tolerance of cassava due its symbiosis is assumed to be VAM's ability to curtail disease infection. The genera, species and the density of VAM affect the degree of retardation of disease infection, enhancement of nutrient absoption, tolerance to soil drought and tolerance to soil salinity.
\end{abstract}

Keywords: Cassava, drought, mycorrhizae, nutrient, salinity

\section{INTRODUCTION}

Cassava (Manihot esculenta Crantz) is commonly planted by Indonesian farmers because it is an important food as a carbohydrate source after rice and maize. As a food source, cassava is consumed in non-processed form (boiled, fermented preparation called tapai, and fried in chips) or in processed form, flour and starch are processed into a variety of food products (Eleazu et al. 2014; Herlina and Nuraeni 2014; National Geographic 2017; Herawati 2015). In general, these plants are planted on infertile soils, such as in upland fields that are poor in P elements (calcareous soils) or in acid-reacting soils. Therefore, fertilizer application is needed to increase the growth and yield of cassava plants (Wargiono 2003).

Microbes as form of fungi are not only known as parasites which cause plants to become sick and even die.such as the fungus Sclerotium rolfsii in soybean plants or other plants (Yaqub and Shahzad 2005; Malinda et al. 2017). Remy et al. (1994) reported the presence of fungi in fossil plant roots that were around 400 million years old. Several studies from several decades ago revealed that sucha fungus was known as Glomales which was associated with plant roots and in fact the fungus could play a role to increase plant growth and production (Soedarjo and Habte 1993 and 1995; Habte and Soedarjo 1995 and 1996; Tong-jian et al. 2010). This association between fungi and plant roots is known as 'mycorrhizae', so they are also known as mycorrhizal fungi (Ruzicka et al. 2013).

Mycorrhizal fungi obtain energy from host plants (Solaiman and Saito 1997; Pfeffer et al. 1999) and host plants obtain additional nutrient uptake such as $\mathrm{P}$ from fungi which causes plants to grow and produce better, especially on soils that are P nutrient deficient (Soedarjo and Habte 1993 and 1995; Allen and Shachar-Hill 2009; Govindarajulu et al. 2005; Javot et al. 2007; Sankaralingam et al. 2016). Besides increasing P uptake, mycorrhizae also increase other nutrient uptake such as $\mathrm{N}, \mathrm{K}, \mathrm{Mg}, \mathrm{Cu}$, Zn (Guissou 2009; Yaseenet al. 2011). Mycorrhizal fungi also increase plant tolerance to water shortages (Aroca et al. 2008; Wu et al. 2011; Chitarra et al. 2016) and also increase disease resistance in various plants (Hwang et al. 1992; Liu et al. 2007; Poovarasan et al. 2013). Thus, this association is 
mutually beneficial and is known as mutualistic symbiosis (Ruzicka, et al., 2013). This review discusses the important role of arbuscular vesicular mycorrhizae in order to enhance cassava growth and productivity.

\section{VESICULAR ARBUSKULARMIKORIZAE}

Vesicular-arbuscular mycorrhizae (VAM) is classified as endomycorrhizal, because vesicular and arbuscular structures are formed in the root cortex tissue of plants. This type of mycorrhizae infects plant roots and hyphae enter the cortical tissue (Figure 1). In cortical tissue, these mycorrhizae form arbuscular and vesicular structures. The tips of mycorrhizal hyphae that exist in the cortical tissue form like clumps of thread and are referred to as 'arbuscular'. While the tip of the hypha that forms a ball-like structure in cortical tissue is called the 'vesicular'. So, this type of mycorrhizae is known as Vesicular-Arbuscular Mycorrhizae (VAM). VAMfungi cannot be propagated with pure culture in the laboratory, but must always be associated with plant roots, because this type of fungus is an 'obligate'. The formation of vesicular and arbuscular indicates that symbiosis has occurred. Arbuscular and vesicular structures are common and are found in the roots of all plants, including cassava (Begoude et al. 2016).

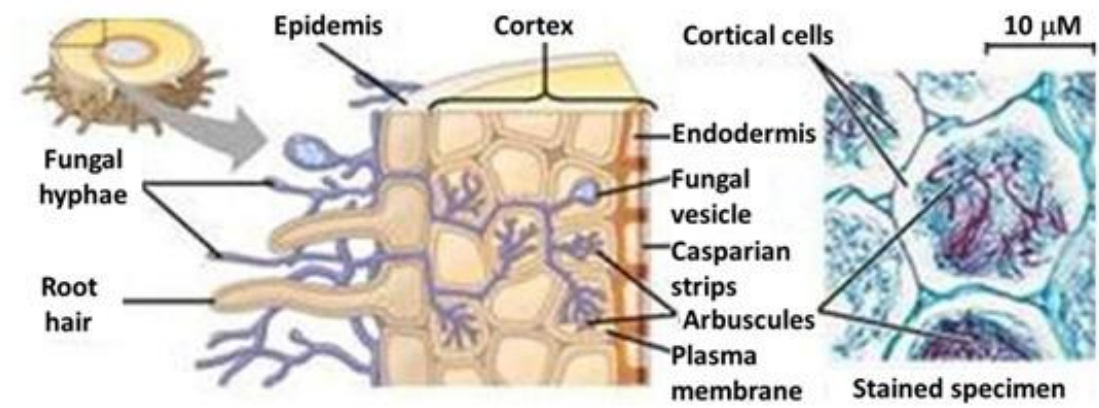

Figure1. Mycorrhizal structures in plant roots in symbiosis with plants.

(http://int.search.myway.com/search/AJimage.jhtml?\&n=781bb8d6\&p2=\%5EY6\%5Echryyy\%5ETT $\mathrm{AB} 02 \% 5$ Eid\&pg $=\mathrm{AJ}$ image $\& \mathrm{pn}=1 \& \mathrm{ptb}=0 \mathrm{E} 8 \mathrm{AF} 6 \mathrm{~B} 1-\mathrm{DB} 8 \mathrm{D}-4687-\mathrm{A} 10 \mathrm{E}$

B08C52D315F\&qs=\&searchfor=endomycorrhizae+image \&ss=sub\&st=tab\&tpr=sbb\&imgs=1p\&filter $=$ on\&imgDetail=true (accessed 26 May 2017)

\subsection{Effect of Mycorrhizae on Growth And Yields of Cassava}

Plant growth and yield, including cassava, are determined by environmental and genetic factors. Environmental factors include the abiotic and biotic environments. Abiotic factors such as climate (air temperature, radiation, humidity, air pressure and rainfall) are not easily changed or modified to support optimal plant growth. Non-climatic abiotic factors such as soil fertility, soil acidity, salinity and relative soil moisture can be modified to improve plant growth. Plant experts define biotic factors in general are pests, diseases and weeds that can inhibit growth and reduce yields and even cause crop failure. The VAM fungus is also a biotic factor that can affect the growth and yield of cassava (Table 2) (Sridevi and Ramakrishnan, 2013).

Plant growth increase was due to improved nutrient uptake by host plants (Sridevi and Ramakrishnan 2013; Sankaralingam, et al., 2016). The Increaseplant growth is also caused by an increasedof plant resistance to diseases (Poovarasan et al., 2013), resistance to water shortages (Chitarra et al. 2016) and resistance to saline conditions (Al-Khaliel, 2010). The benefits of mycorrhizae in enhancing plant growth and yield are also determined by mycorrhizal types and host species and even varieties of certain plant types (Azcon and Ocampo, 1981; Tawaraya, 2003; Ristiyanti, et al. 2014; Rias et al. 2014).

Table2. Effect of Glomus fasciculatum inoculation on plant height (cm) at 150 days after planting and yield of cassava tubers $(t / h a)$

\begin{tabular}{|c|c|c|}
\hline Treatment & Plant height $(\mathrm{cm})$ & Yield of cassava tubers (t/ha) \\
\hline Control & 131.93 & 16.790 \\
\hline Mycorrhizae $(\mathrm{M})$ & 140.67 & 20.571 \\
\hline $25 \%$ NPK $(25: 25: 40) / \mathrm{ha}$ & 149.53 & 26.124 \\
\hline
\end{tabular}


Mutualistic Symbiosis between Arbuscular Visicular Mycorrhizal Fungi with Cassava Plant(Manihot esculenta Crantz)

\begin{tabular}{|c|c|c|}
\hline 100\% NPK (100:100:160)/ha & 192.53 & 33.120 \\
\hline $\mathrm{M}+25 \% \mathrm{NPK} / \mathrm{ha}$ & 174.59 & 29.154 \\
\hline $\mathrm{M}+100 \% \mathrm{NPK} / \mathrm{ha}$ & 198.19 & 34.152 \\
\hline
\end{tabular}

Source: Sridevi and Ramakrishnan (2013).

\subsection{Dependence of Cassava on Vesicular Arbuscular Mycorrhizal Fungi}

The degree of plant dependence on vesicular arbuscular mycorrhizal (VAM) fungi is usually measured by the degree of infection, the degree of nutrient uptake and the rate of growth and yield of plants. The degree of plant dependence on VAM fungi is determined by the genotype of the host plant and also the VA mycorrhizal fungal genotype at the level of genus, species and even varieties (Table 1) (Azcon and Ocampo, 1981, Howeler 1982, Sharma et al. 1996, Bâi et al. 2000 , Kaeppler et al. 2000, Tawaraya K 2003, Zachée et al. 2008, Al-Qarawi and Al-Syahrani, 2010, Tong-jian et al. 2010, Jiang et al. 2013, He et al. 2014). The results of research by Graham and Syvertsen (1985) showed that plants abundant in fine roots were found to be have less dependant on VAM fungi than plants with few fine roots. Cassava has a few fine roots, so the cassava plants are highly dependant on VA mycorrhizal fungi (Howeler, 1982; Okon, 2011,). Cassava inoculation with VA mycorrhizae can significantly increase growth and yield (see Table 2) (Sridevi and Ramakrishnan 2013). However, the dependence of several cassava varieties on different VA mycorrhizae causes the growth to increase as well (Begoude et al. 2016).

Table1. The degree of plant dependence on VAMfungi

\begin{tabular}{|c|c|c|c|}
\hline Type of plant & Type of VAMfungi & $\begin{array}{c}\text { Depend- } \\
\text { ence } \\
(\%)\end{array}$ & Sources \\
\hline $\begin{array}{c}\text { Cassava(Manihot esculenta Crantz) } \\
\text { cv TMS 4(2)1425 }\end{array}$ & Glomus deserticola & 54 & Okon et al. 2010 \\
\hline $\begin{array}{c}\text { Cassava(Manihot esculenta Crantz) } \\
\text { cv. TMS } 30572\end{array}$ & Glomus deserticola & 77 & Okon, 2011 \\
\hline $\begin{array}{c}\text { Cassava (Manihot esculenta Crantz) } \\
\text { cv. Nina } \\
\end{array}$ & $\begin{array}{l}\text { Mycorrhizal inoculum from } \\
\text { cassava roots }\end{array}$ & 51 & Howeler , 1982 \\
\hline $\begin{array}{c}\text { Cassava (Manihot esculenta Crantz) } \\
\text { cv. Pata de Paloma }\end{array}$ & $\begin{array}{l}\text { Mycorrhizal inoculum from } \\
\text { cassava roots }\end{array}$ & 29 & Howeler, 1982 \\
\hline $\begin{array}{c}\text { Cassava (Manihot esculenta Crantz) } \\
\text { cv M Aus7 }\end{array}$ & $\begin{array}{l}\text { Mycorrhizal inoculum from } \\
\text { cassava roots }\end{array}$ & 37 & Howeler , 1982 \\
\hline $\begin{array}{c}\text { Cassava (Manihot esculenta Crantz) } \\
\text { cv M Aus } 8\end{array}$ & $\begin{array}{l}\text { Mycorrhizal inoculum from } \\
\text { cassava roots }\end{array}$ & 14 & Howeler , 1982 \\
\hline $\begin{array}{c}\text { Cassava (Manihot esculenta Crantz) } \\
\text { cv M Aus } 10\end{array}$ & $\begin{array}{l}\text { Mycorrhizal inoculum from } \\
\text { cassava roots }\end{array}$ & 16 & Howeler , 1982 \\
\hline $\begin{array}{c}\text { Cassava (Manihot esculenta Crantz) } \\
\text { cv M Aus } 20\end{array}$ & $\begin{array}{l}\text { Mycorrhizal inoculum from } \\
\text { cassava roots }\end{array}$ & 48 & Howeler , 1982 \\
\hline $\begin{array}{c}\text { Cassava (Manihot esculenta Crantz) } \\
\text { cv M Aus } 21\end{array}$ & $\begin{array}{l}\text { Mycorrhizal inoculum from } \\
\text { cassava roots }\end{array}$ & 37 & Howeler , 1982 \\
\hline $\begin{array}{c}\text { Cassava (Manihot esculenta Crantz) } \\
\text { cv CMC } 72\end{array}$ & $\begin{array}{l}\text { Mycorrhizal inoculum from } \\
\text { cassava roots }\end{array}$ & 27 & Howeler, 1982 \\
\hline Rice (Oryza sativa) & $\begin{array}{l}\text { Mycorrhizal inoculum from } \\
\text { cassava roots }\end{array}$ & 9 & Howeler , 1982 \\
\hline Maize (Zea mays L.) & $\begin{array}{l}\text { Mycorrhizal inoculum from } \\
\text { cassava roots }\end{array}$ & 15 & Howeler , 1982 \\
\hline Acacia nilotica var. cupriciformis & Glomus spp & 18 & Sharma et al. 1996 \\
\hline Groundnut(Arachis hypogaea L.) & Glomus sp. and Gigaspora sp. & 86 & Zachée et al. 2008 \\
\hline Mungbean (Vigna radiata) & Glomus caledonium 90036 & 58 & $\begin{array}{l}\text { Tong-jian et al. } \\
2010\end{array}$ \\
\hline Maize (Zea mays L) var. Mo17 & $\begin{array}{c}\text { Mixed of G. etunicatum, G. } \\
\text { clarum, G. intraradices, A. mellea }\end{array}$ & 40 & $\begin{array}{l}\text { Kaeppler et al. } \\
2000 \\
\end{array}$ \\
\hline Maize (Zea mays L) var. B37 & $\begin{array}{l}\text { Mixed of G. etunicatum, } G . \\
\text { claroideum, A. mellea }\end{array}$ & 62 & $\begin{array}{l}\text { Kaeppler et al. } \\
2000\end{array}$ \\
\hline Maize (Zea mays L) var. W59M & $\begin{array}{c}\text { Mixed of G. etunicatum, G. } \\
\text { clarum, G. intraradices, A. mellea }\end{array}$ & 76 & $\begin{array}{l}\text { Kaeppler et al. } \\
2000 \\
\end{array}$ \\
\hline
\end{tabular}

International Journal of Research Studies in Agricultural Sciences (IJRSAS)

Page | 10 
Mutualistic Symbiosis between Arbuscular Visicular Mycorrhizal Fungi with Cassava Plant(Manihot esculenta Crantz)

\begin{tabular}{|c|c|c|c|}
\hline $\begin{array}{c}\text { Bamboo hybrid, crosses between } \\
\text { Bambusa pervariabilis and } \text { B. grandis }\end{array}$ & Glomus intraradices BEG 193 & 46 & Jiang et al. 2013 \\
\hline $\begin{array}{c}\text { Bamboo hybrid, crosses between } \\
\text { Bambusa pervariabilis and B. grandis }\end{array}$ & G. intraradices BEG 141 & 35 & Jiang et al. 2013 \\
\hline $\begin{array}{c}\text { Bamboo hybrid, crosses between } \\
\text { Bambusa pervariabilis andB. grandis }\end{array}$ & G. mosseae BEG 167 & 37 & Jiang et al. 2013 \\
\hline $\begin{array}{c}\text { Bamboo hybrid, crosses between } \\
\text { Bambusa pervariabilis andB. grandis }\end{array}$ & G.etunicatum BEG 168 & 43 & Jiang et al. 2013 \\
\hline
\end{tabular}

Note: Dependency is measured by formula $=$ (plant weight or yield of mycorrhizal seeds - weight of plants or yield of seeds without mycorrhizae) / (weight of plants or yields of bermororiza seeds) $x 100 \%$.

\section{VAMFUNGI AND NUTRIENT UPTAKE ON CASSAVA}

Cassava is generally planted on infertile (sub-optimal) soils in Indonesia, such as acid soils and upland soils that does not get technical irrigation (Saleh and Widodo, 2007), so the average production is lower than the yield potential of varieties which has been released by the Agency for Agricultural Research and Development (Balitkabi 2016).Fertilization is reported to increase cassava yields (Ispandi, 2003; Wargiono, 2003; Prasetyo et al, 2014). Table 2 shows that increased plant height and cassava yields due to NPK fertilization can largely be substituted by the inoculation of the VAM fungus, Glomus fasciculatum (Table 2) (Sridevi and Ramakrishnan, 2013). These results indicate that VA fungi help host plants increase nutrient uptake.

VAM fungus inoculation was reported to increase absorption of macro and micro nutrients by cassava plants and was followed by a significant increase in tuber yield (Table 3) (Carretero et al. 2009, Okon et al. 2010, Oyetunji et al., 2017).VAMfungi are also reported to increase growth and yields followed by increased nutrient uptake by other plants (Soedarjo and Habte. 1993 and 1995; Govindarajulu et al., 2005; Javot et al., 2007; Allen and Shachar-Hill, 2009; Guissou , 2009; Yaseen et al., 2011; Sankaralingam, et al., 2016). Thus, VA mycorrhizal fungi increase plant growth and yield through a mechanism of increasing nutrient uptake.

Table2. Effect of Glomus fasciculatum inoculation on plant height (cm) at 150 days after planting and yield of cassava tubers $(t / h a)$

\begin{tabular}{|c|c|c|}
\hline Treatments & Plant height $\mathbf{( c m )}$ & Yield of cassava tubers (t/ha) \\
\hline Control & 131.93 & 16.79 \\
\hline Mycorrhiza $(\mathrm{M})$ & 140.67 & 20.57 \\
\hline $25 \%$ NPK $(25: 25: 40) / \mathrm{ha}$ & 149.53 & 26.12 \\
\hline $100 \%$ NPK $(100: 100: 160) / \mathrm{ha}$ & 192.53 & 33.12 \\
\hline M+25\% NPK/ha & 174.59 & 29.15 \\
\hline M+100\% NPK/ha & 198.19 & 34.15 \\
\hline
\end{tabular}

Source: Sridevi and Ramakrishnan (2013).

\subsection{The VAM Fungi Prevent Cassava Plants from Infectious Diseases}

Plant diseases caused by viruses, fungi or bacteria are important obstacles to plant growth and yield and can cause crop failure. Important diseases of cassava are caused by white root fungus (Rigidoporus microporus), bacterial blight and bacterial wilt (Indonesia Bertanam, 2014). White root fungus disease also infected the roots of rubber plants and inoculation with mycorrhizal fungi was reported to reduce the degree of infection by white root fungi up to 66\% (Putri et al., 2016). Likewise, as a root crop, cassava could be protected from damage of white root fungus by the presence of adequate amount of VA fungi in the soils.

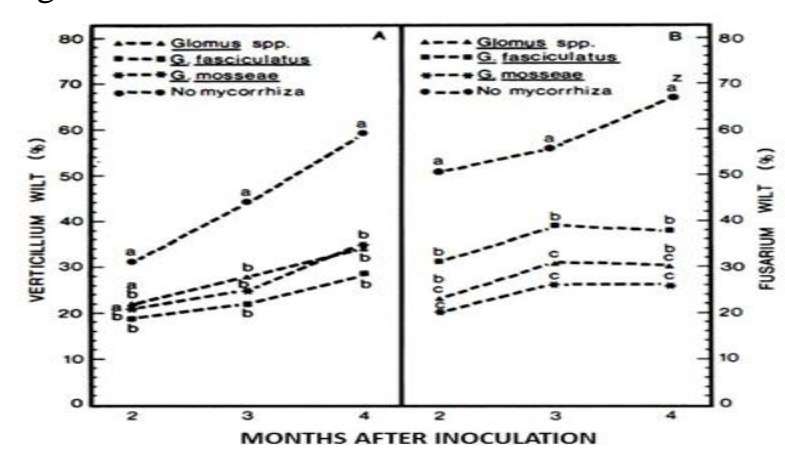

Figure2. Effect of mycorrhizal inoculation on the degree of withering of alfalfa plants by Verticillium alboatrum or Fusarium oxysporum $f$. sp. medicaginis. 
Source: Hwang et al. 1992

Fungal diseases caused by Verticillium albo-atrum or Fusarium oxysporum $f$. sp. medicaginis can cause the wilting of alfalfa plants and failureof harvest. Figure 2 shows that inoculation with mycorrhizal fungi reduces the degree of wilt in alfalfa caused by Verticillium albo-atrum (A) and Fusarium oxysporum f. sp. medicaginis (B) and the effectiveness of each type of mycorrhiza in suppressing the disease is different (Hwang et al. 1992). The VAMG. margaritafungi is effective in reducing the intensity of wilt disease in soybean plants caused by the fungus Rhizoctonia solani (Figure 3) and the degree of reduction depends on mycorrhizal dose (Rozy et al. 2004).

The damage intensity due to the Blood Disease Bacterium (BDB) in banana plants can also be significantly reduced by the use of the VAMfungi and the effectiveness of this fungus is determined by the mycorrhizalgenera (Suswati et al. 2013). The damage intensity due to wilt disease Fusarium oxysporum f. sp. Lycopersici in tomato plants decreased significantly with the inoculation of the VAMfungi (Figure 4 A and B) (Pedai et al. 2015). Salami and Olawole (2011) also reported the role of VA mycorrhizae in protecting jute plants from Phytophthora infestans. Until this review was made, there has been no study of the effect of mycorrhizae on decreasing damages by such a disease on cassava plants. However, from the results of studies on plants other than cassava, mycorrhizal inoculation was expected to suppress the disease infection, especially diseases caused by fungi.

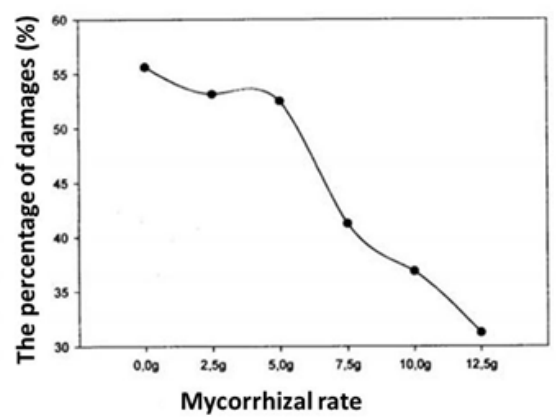

Figure3. Effect of G. margarita mycorrhizal inoculation dose on the intensity of wilt disease (Rhizoctonia solani) on soybean plants.

Source: Rozy et al. 2004
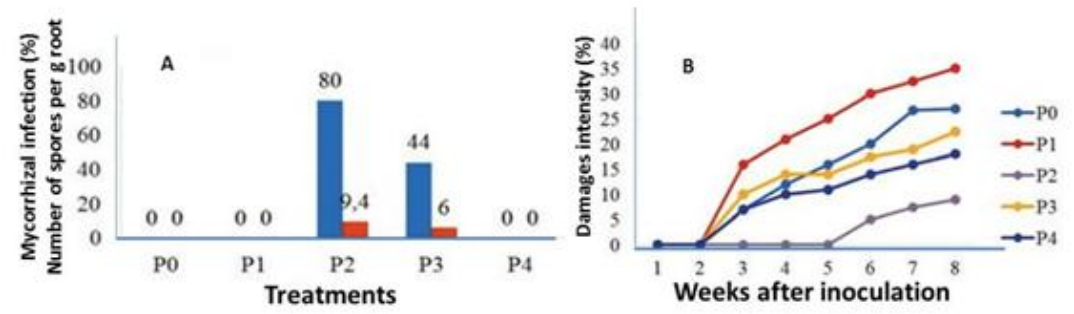

Figure4. Degree of VA mycorrhizal fungal infection (\%) in tomato root and spore density (spore / g) (A) and intensity of Fusarium oxysporum wilt attack $f$. sp. lycopersici in tomato plants $(B)$. The blue and red histograms (A) are infections (\%) and the number of VA mycorrhizal fungal spores per gram of root. PO: tomato plants without inoculation with mycorrhizal fungi and without inoculation with Fusarium oxysporum $f$. sp. lycopersici, P1: inoculation with Fusarium oxysporum $f$. sp. lycopersici, P2: inoculation with VA mycorrhizal fungi, P3: inoculation with Fusarium oxysporum $f$. sp. lycopersici and VA and P4 mycorrhizal fungi: inoculation with Fusarium oxysporum f. sp. lycopersici and sprayed with benomyl $0.2 \mathrm{~g} / \mathrm{l}$.

Source: Pedai et al. 2015

\subsection{VAM Fungus and Lack of Water in Cassava Plants}

Water is the largest component of plants and as a basic material in the process of photosynthesis and evapotranspiration. Thus, lack of water will reduce the rate of photosynthesis and as consequently, the growth will be hampered and yields will decresease remarkably (Table 3) (Ruiz-Lozano et al. 1995, Mwanamwenge 1999, Cakir 2004). In drought stress conditions, plants usually produce more proline to prevent cell damage because proline is one of the important osmopolitans of plants (Yoshiba et al 1997). Thus, plants that are relatively tolerant of drought stress will produce relatively more proline 
than plants that are sensitive to drought stress. Table 3 shows that lettuce plants that established micororrhizal association contain higher levels of proline than those without micororrhizae. As a result, the mycorrhizal lettuce plants grow better and produce significantly higher biomass. Thus, mycorrhizal fungi increase plant tolerance to drought stress through increased levels of leaf proline. Proline is a general phenomenon produced higher in drought stress tolerant.

Table3. Dry weight of lettuce plants in conditions of water adequacy and conditions of water shortage

\begin{tabular}{|c|c|c|c|c|c|c|}
\hline \multirow[b]{2}{*}{ Treatments } & \multicolumn{3}{|c|}{ Water adequacy } & \multicolumn{3}{|c|}{ Water shortage } \\
\hline & $\underset{\text { (g/plant) }}{\text { PDW }}$ & $\begin{array}{c}\text { Root } \\
\text { Infection } \\
(\%)\end{array}$ & $\begin{array}{c}\text { Leaf Prolin } \\
\text { (nmol/g) }\end{array}$ & $\begin{array}{c}\text { PDW } \\
\text { (g/plant) }\end{array}$ & $\begin{array}{c}\text { Root } \\
\text { Infection } \\
(\%)\end{array}$ & $\begin{array}{c}\text { Leaf Prolin } \\
\text { (nmol/g) }\end{array}$ \\
\hline Control & $0.56 \mathrm{k}$ & 0 & $123 \mathrm{~g}$ & 0.151 & 0 & $16.2 \mathrm{~g}$ \\
\hline $\mathrm{PO}^{-3}$ & $1.15 \mathrm{j}$ & 0 & $148 \mathrm{~g}$ & 0.261 & 0 & $16.4 \mathrm{~g}$ \\
\hline G. deserticola & $6.00 \mathrm{a}$ & $92.3 \mathrm{a}$ & $79.3 \mathrm{bcd}$ & $5.50 \mathrm{bc}$ & $941 \mathrm{a}$ & $119.6 \mathrm{a}$ \\
\hline G. etunicatum & $5.94 \mathrm{ab}$ & $59.4 d$ & $62.8 \mathrm{cde}$ & $4.98 \mathrm{~d}$ & $655 \mathrm{~cd}$ & 93.4ab \\
\hline G. intraradices & $5.43 \mathrm{c}$ & $86.5 \mathrm{ab}$ & $57.8 \mathrm{def}$ & $4.52 \mathrm{e}$ & $865 \mathrm{ab}$ & $40.8 \mathrm{ef}$ \\
\hline G. fasciculatum & $5.08 \mathrm{~d}$ & $68.5 \mathrm{~cd}$ & 50.0def & $4.39 \mathrm{e}$ & $632 \mathrm{~cd}$ & $94.7 \mathrm{ab}$ \\
\hline G. mosseae & $4.54 \mathrm{e}$ & $69.7 \mathrm{c}$ & $38.3 \mathrm{ef}$ & $3.87 \mathrm{f}$ & $794 b$ & 79.4bcd \\
\hline G. caledonium & $3.53 \mathrm{~g}$ & $32.6 \mathrm{f}$ & $30.5 \mathrm{f}$ & $2.70 \mathrm{~h}$ & $272 \mathrm{f}$ & 42.6ef \\
\hline G. occultum & $2.20 \mathrm{i}$ & $42.0 \mathrm{e}$ & $50.8 \mathrm{def}$ & $0.67 \mathrm{k}$ & $320 \mathrm{f}$ & $87.9 \mathrm{bc}$ \\
\hline
\end{tabular}

Note: $P D W=$ plant dry weight.

Figures in the same column followed by the same letter are not significantly different at the LSD 5\% test level.

Source: Ruiz-Lozano et al., 1995

In addition to proline, mycorrhizae cause higher leaf chlorophyll content and an increase in leaf chlorophyll content is followed by an increase in dry weight of cassava plants as an indicator of plant growth rate (Table 4, Ekanayake et al. 2004). Leaf chlorophyll is a vital part of plants to carry out photosynthesis. The higher the chlorophyll content of leaves up to a certain level, the higher the photosynthetic activity and the more photosynthates produced. So that the VAM fungus can increase plant growth (see Table 4, Ekanayake et al. 2004).

Table4. Effect of AV mycorrhizal inoculation on total chlorophyll content of cassava leaves

\begin{tabular}{|c|c|c|}
\hline \multirow{2}{*}{ Treatments } & \multicolumn{2}{|c|}{ Chlorophyll content of cassava leaves (mg/l) } \\
\hline & TMS 4(2)1425 & TME1 \\
\hline & \multicolumn{2}{|c|}{1 month after planting } \\
\hline G. clarum & $6.27 \mathrm{a}$ & $6.03 \mathrm{a}$ \\
\hline G. mosseae & $5.49 \mathrm{~b}$ & $6.06 \mathrm{a}$ \\
\hline \multirow[t]{2}{*}{ Tanpa inokulasi } & $5.11 \mathrm{~b}$ & $5.31 \mathrm{~b}$ \\
\hline & \multicolumn{2}{|c|}{2 months after planting } \\
\hline G. clarum & $6.95 \mathrm{a}$ & $5.78 \mathrm{a}$ \\
\hline G. mosseae & $6.29 \mathrm{a}$ & $5.78 \mathrm{a}$ \\
\hline Tanpa inokulasi & $5.05 \mathrm{~b}$ & $5.03 \mathrm{~b}$ \\
\hline
\end{tabular}

Source: Ekanayake et al. 2004.

\section{VAM Fungi and Salinity in Cassava Plants}

Salinity is a term to describe the degree of salt $(\mathrm{NaCl})$. Saline condition (high salt content) can inhibit plant growth and yield, including cassava (Al-khalil 2010). Decrease in plant growth and yield under saline conditions is associated with the decreasedof photosynthetic rate, the decrease of leaf chlorophyll content, low nutrient uptake and $\mathrm{Na}$ accumulation in plant roots (Luiz-Rosano et al. 1996, Feng et al. 2002, Dudhane et al.2011). Interestingly, the presence of mycorrhizae in the roots of host plants was reported to increase plant growth and tolerance in saline conditions. Increased plant growth under saline condition is associated with an increase in the rate of photosynthesis, an increase in leaf chlorophyll content, an increase in plant nutrient content, an increase in leaf and plant moisture content, a decrease in the Na content of peanut plants (Tables 5 and 6, Luiz-Rosano et al.1996; Feng et al.2002; Cantos et al.2008, Sheng et al.2008, Al-Khaliel 2010, Dudhane et al.2011). However, mycorrhizal effectiveness in reducing the negative effects of saline conditions depends on the type of mycorrhizal fungi and plant genotypes (Ruiz-Rosano et al.1996; Carretero et al.2008, Al-khalil 2010). 
Mutualistic Symbiosis between Arbuscular Visicular Mycorrhizal Fungi with Cassava Plant(Manihot esculenta Crantz)

Water and chlorophyll are important components in plant photosynthesis. Thus, the rate of photosynthesis of mycorrhizal plants is better than that of non-mycorrhizal plants and this condition will cause plants to grow and produce better.

Table5. Effect of salinity on nutrient uptake and chlorophyll content of peanut leaves in inoculated or not inoculated conditions with VA mycorrhizal fungi (Glomus mosseae)

\begin{tabular}{|c|c|c|c|c|c|c|}
\hline \multirow{2}{*}{$\begin{array}{c}\text { NaCl } \\
(\mathbf{M})\end{array}$} & \multirow{2}{*}{ InoculationmycorrhizalVA } & \multicolumn{2}{|c|}{ Leaves nutrient concentration(\%) } & Chlorophyll(mg/g \\
\cline { 3 - 6 } & & $\mathbf{N}$ & $\mathbf{P}$ & $\mathbf{K}$ & $\mathbf{N a}$ & $\mathbf{P}$ ) \\
\hline 0.0 & - & 2.54 & 0.12 & 1.25 & 0.02 & 1.98 \\
\hline 0.0 & + & 2.98 & 0.22 & 1.75 & 0.03 & 3.88 \\
\hline 0.1 & - & 2.46 & 0.10 & 1.18 & 0.02 & 1.90 \\
\hline 0.1 & + & 3.26 & 0.26 & 1.90 & 0.03 & 4.02 \\
\hline 0.2 & - & 2.28 & 0.10 & 1.02 & 0.02 & 1.81 \\
\hline 0.2 & + & 3.02 & 0.20 & 1.40 & 0.03 & 3.70 \\
\hline 0.3 & - & 2.12 & 0.09 & 1.00 & 0.02 & 1.52 \\
\hline 0.3 & + & 2.51 & 0.20 & 1.26 & 0.04 & 3.16 \\
\hline 0.5 & - & 2.02 & 0.09 & 0.98 & 0.02 & 1.30 \\
\hline 0.5 & + & 2.38 & 0.18 & 1.20 & 0.04 & 2.84 \\
\hline
\end{tabular}

$V A=$ vesicular arbuscular,

$P F W=$ plant fresh weight

$+=$ inoculated with mycorrhiza; - = not inoculated with mycorrhizae;

Source: Al-khalil 2010

Table6. Effect of VAM fungi on the fresh and dry weight of roots, stems and plants (roots + stems + leaves) cassava at 60 days after planting

\begin{tabular}{|c|c|c|c|c|c|c|c|c|}
\hline \multirow{2}{*}{$\begin{array}{c}\text { Cassava } \\
\text { clones }\end{array}$} & \multicolumn{2}{|c|}{$\operatorname{Root}(\mathrm{mg})$} & \multicolumn{2}{|c|}{ Stem(mg) } & \multicolumn{2}{|c|}{ Leave(mg) } & \multicolumn{2}{|c|}{ Plant(mg) } \\
\hline & FW & DW & FW & DW & FW & DW & FW & DW \\
\hline \multicolumn{9}{|c|}{ Clone SOM-1 } \\
\hline Mycorrhiza- & 99 & 55 & 948 & 231 & 1,150 & 202 & 2,197 & 489 \\
\hline \multirow[t]{2}{*}{ Mycorrhiza+ } & 1659 & 474 & 14000 & 2777 & 9727 & 1937 & 25386 & 5188 \\
\hline & $* *$ & $* *$ & $* *$ & $* *$ & $* *$ & $* *$ & $* *$ & $* *$ \\
\hline \multicolumn{9}{|c|}{ Clone 05} \\
\hline Mycorrhiza- & 37 & 17 & 382 & 77 & 332 & 72 & 751 & 166 \\
\hline \multirow[t]{2}{*}{ Mycorrhiza+ } & 529 & 172 & 4930 & 880 & 4383 & 844 & 9842 & 1896 \\
\hline & $* *$ & $* *$ & $* *$ & $* *$ & $* *$ & $* *$ & $* *$ & $* *$ \\
\hline \multicolumn{9}{|c|}{ Clone 50} \\
\hline Mycorrhiza- & 32 & 24 & 385 & 102 & 343 & 73 & 760 & 199 \\
\hline \multirow[t]{2}{*}{ Mycorrhiza+ } & 360 & 127 & 4405 & 811 & 5542 & 962 & 10306 & 1899 \\
\hline & $* *$ & $* *$ & $* *$ & $* *$ & $* *$ & $* *$ & $* *$ & $* *$ \\
\hline
\end{tabular}

$F W=$ fresh weight $; D W=$ dry weight

** Significantly different at $P=0.01$ from the Studied Test

Source: Carretero et al. 2009

\section{CONCLUSION}

Vesicular-arbuscular mycorrhizal fungus (VAM) establishes symbiosis with plants, including cassava. This symbiosis is mutualistic and obligate, VAM fungi obtain energy sources from host plants and increase nutrient uptake by host plants. As a results, the mycorrhizal plants grow and yield better. Additionally, the mycorrhizal plants are more tolerant efto diseases, water stress and salt stress (high salinity). However, the genetic background of VAM fungi and host plants significantly affected the symbiosis

\section{REFERENCES}

[1] Allen, JW and Shachar-Hill Y. 2009. Sulfur transfer through an arbuscular mycorrhiza. Plant Physiol. 149:549-560.

[2] Al-Khaliel AS. 2010. Effect of salinity stress on mycorrhizal association and growth response of peanut infected by Glomus mosseae. Plant Soil Environ. 56: 318-324. 
[3] Al-Qarawi AA and Alshahrani TS. 2010. Growth resnponses of two species of Zizyphus to inoculation with arbuscular mycorrhizal fungi. JKAU. Met.Env. \& Arid Land Agric. Sci. 21: 109-122.

[4] Aroca R, Vernieri P and Ruiz-Lozano JM. 2008. Mycorrhizal and non-mycorrhizal Lactuca sativa plants exhibit contrasting responses to exogenous ABA during drought stress and recovery. J. Exp. Bot. 59: 2029-2041.

[5] Azcon R and Ocampo JA. 1981. Factors affecting the vesicular-arbuscular infection and mycorrhizal dependency of thirteen wheat cultivars. New Phytol. 87: 677-685.

[6] Balitkabi. 2016. Deskripsi varietas unggul aneka kacang dan umbi, Balai Penelitian Tanaman aneka Kacang dan Umbi.

[7] Bâi AM, Plenchette C, Danthu P, Duponnois R and Guissou T. 2000. Functional compatibility of two arbuscular mycorrhizae with thirteen fruit trees in Senegal. Agroforestry Systems 50: 95-105.

[8] Begoude DAB, Sarr PS, Mpon TLY, Owona DA, Kapeua MN and Arak S. 2016. Composition of arbuscular mycorrhizal fungi associated with cassava (Manihot esculenta Crantz) cultivars as influenced by chemical fertilization and tillage in Cameroon. J Appl. Biosci. 98: 9270-9283.

[9] Cakir R. 2004. Effect of water stress at different development stages on vegetative and reproductive growth of maize. Field Crops Res. 89: 1-16.

[10] Carretero CL, Cantos M, Garc'ra JL, Azc'on R and Troncoso A. 2008. Arbuscular-mycorrhizal contributes to alleviation of salt damage in cassava clones. Journal of Plant Nutrition 31: 959-971

[11] Carretero CL, Cantos M, Garc'ia JL, Rosario Azc'on R and Troncoso A. 2009.Growth Responses of Micropropagated CassavaClones as Affected by Glomus Intraradices Colonization. J. Plant Nutr. 32: 261273.

[12] Chitarra W, Pagliarani C,Maserti B, Lumini E, Siciliano I, Cascone P, Schubert A, Gambino, G, Balestrini $\mathrm{R}$ and Guerrieri E. 2016. Insights on the Impact of Arbuscular Mycorrhizal Symbiosis on Tomato Tolerance to Water Stress.Plant Physiol. 171: 1009-1023.

[13] Dudhane MP, Borde MY and Jite PK. 2011, Effect of arbuscular mycorrhizal fungi on growth and antioxidant activity in Gmelina arborea roxb, Under salt stress condition, Not Sci Biol 3:71-78.

[14] Ekanayake IJ, Oyetunji OJ, Osonubi O and Lyasse O. 2004. The effects of arbuscular mycorrhizal fungi and water stress on leaf chlorophyll production of cassava (Manihot esculenta Crantz). Food Agric. \& Environ. 2: 190-196.

[15] Eleazu OC, Eleazu KC and Kolawole S. 2014.Use of indigenous technology for the production of high quality cassava flour with similar food qualities as wheat flour. Acta Sci. Pol., Technol. Aliment. 13: 249256

[16] Feng G, Zhang FS, Li XL, Tian CY, Tang C and Rengel Z. 2002. Improved tolerance of maize plants to salt stress by arbuscular mycorrhiza is related to higher accumulation of soluble sugars in roots. Mycorrhiza 12:185-190.

[17] Govindarajulu M, Pfeffer PE, Jin H, Abubaker J, Douds DD, Allen JW, Bücking H, Lammers PJ, and Shachar-Hill Y. 2005. Nitrogen transfer in the arbuscular mycorrhizal symbiosis. Nature 435: 819-823.

[18] Graham JH and Syvertsen JP. 1985. Host determinants of mycorrhizal dependency of citrus rootstock seedlings. New Phytol. 101: 667-676.

[19] Guissou, T. 2009. Contribution of arbuscular mycorrhizal fungi to growth and nutrient uptake by jujube and tamarind seedlings in a phosphate (P)-deficient soil.Afric. J. Microbiol. Res. 3:, 297-304.

[20] Habte M and Soedarjo M. 1995. Mycorrhizal inoculation effect in Acacia mangium grown in an acid oxisol amended with gypsum. J. Plant nutr. 18: 2059-2073.

[21] Habte, M, and Soedarjo M. 1996.Response of Acacia mangium to vesicular arbuscular mycorrhizal inoculation, soil $\mathrm{pH}$, and soil $\mathrm{P}$ concentration. Can. J. Bot. 74: 155-161.

[22] He L, Yang H, Yu Z, Tang J, Xu L and Chen X. 2014. Arbuscular mycorrhizal fungal phylogenetic groups differ in affecting host plants along heavy metal levels. J. Environ. Sci. 26: 2034 - 2040.

[23] Herawati H. 2017. Resep aneka variasi olahan singkong kue modern.http://carabuatresep.blogspot.co.id /2015/11/11-resep-variasi-singkong-kue-modern.html (Accessed 2 Nopember 2017)

[24] Herlina E dan Nuraeni F. 2014.Pengembangan produk pangan fungsional berbasis ubi kayu (Manihot esculenta) dalam menunjang ketahanan pangan. J. Sains Dasar 3: 142-148.

[25] Howeler RH. 1982. Establishment of an effective endomycorrhizal association on cassava in flowing solution culture and its effects on phosphorus nutrition. New Phytol. 90: 229-238.

[26] Hwang SF, Chang KF and Chakravarty P. 1992. Effects of Vesicular-Arbuscular Mycorrhizal Fungi on the Development of Verticillium and Fusarium Wilts of Alfalfa. Plant Dis. 76: 239-243 
[27] Indonesia Bertanam.2014. Beberapa Penyakit Penting pada Tanaman Singkong dan Pengendaliannya, https://indonesiabertanam,com/2014/12/23/beberapa-penyakit-penting-pada-tanaman-singkong-danpengendaliannya/ (Accessed 7 juli 2017).

[28] Ispandi A. 2003. Pemupukan P, K dan waktu pemberian pupuk k pada tanaman ubikayu di lahan kering vertisol ( $\mathrm{P}, \mathrm{K}$ fertilization and frequency of $\mathrm{k}$ fertilizer application on cassava in vertisol upland). Ilmu Pertanian 10: 35-50.

[29] Javot H, Pumplin N, and Harrison MJ. 2007. Phosphate in the arbuscular mycorrhizal symbiosis: Transport properties and regulatory roles, Plant Cell Environ, 30: 310 - 322,

[30] Jiang W, Gou G and Ding Y. 2013. Influences of arbuscular mycorrhizal fungi on growth and mineral element absorption of chenglu hybrid bamboo seedlings. Pak. J. Bot., 45: 303-310.

[31] Kaeppler SM, Parke JL, Mueller SM, Senior L, Stuber C and Tracy WF. 2000. Variation among Maize Inbred Lines and Detection of Quantitative Trait Loci for Growth at Low Phosphorus and Responsiveness to Arbuscular Mycorrhizal Fungi. Crop Sci. 40: 358-364.

[32] Liu J, Maldonado-Mendoza I, Lopez-Meyer M, Cheung F, Town CD and Harrison MJ. 2007. Arbuscular mycorrhizal symbiosis is accompanied by local and systemic alterations in gene expression and an increase in disease resistance in the shoots. Plant J. 50: $529-544$.

[33] Luiz-Rosano JM, Azcon R and Gomez M. 1995. Effects of arbuscular-mycorrhizal glomus species on drought tolerance: physiological and nutritional plant responses. Appl. and Environ. Microbiol. 61: 456460.

[34] Luiz-Rosano JM; Azcon R and Gomez M. 1996.Alleviation of salt stress by arbuscular-mycorrhizal Glomus sp, in Lactuca sativa plants. Physiol. Plantarum 98: 767-772.

[35] Malinda N, Suryanto D dan Nurtjahja K. 2017. Penghambatan serangan Sclerotium rolfsii Penyebab rebah Kecambah pada kedelai dengan bakteri kitinolitik, http://download, portalaruda, org/article,php?article=58519\&val=4113 (Accessed 23 March 2017)

[36] Mwanamwenge J, Loss SP, Siddique KHM and Cocks PS. 1999.Effect of water stress during floral initiation, flowering and podding on the growth and yield of faba bean (Vicia fabaL.).Europ. J. Agron. 11: $1-11$.

[37] National Geographic. 2017. National Geographic 2017. Pengolahan Singkong jadi 13 Produk Turunan.http://nationalgeographic.co.id/berita/2012/05/pengolahan-singkong-jadi-13-produk-turunan (Accessed 6 July 2017).

[38] Okon IE, Solomon MG and Osonubi O. 2010.The effects of arbuscular mycorrhizal fungal inoculation and mulch of contrasting chemical composition on the yield of cassava under humid tropical conditions. The Sci. World J. 10: 505-511.

[39] Okon IE. 2011. Field response of two cassava genotypes inoculated with arbuscular mycorrhizal fungus to Glirisidia sepium mulch to a tropical Alfisol. Bot. Res. Interntl. 4: 04-08

[40] Oyetunji OJ, Ekanayake IJ, Osonubi O and Lyasse O. 2017. Cassava macro- and micronutrient uptake and partitioning in alley cropping as influenced by Glomus spp, in sub-humid tropics and its impact on productivity, http://ciat-library,ciat,cgiar,org/articulos_ciat/cbn/Posters-PDF/Oyetunji\%20et\%20al\%20pos ter $\% 20$ of\%20CBN6,pdf (Accessed 8 Juni 2017)

[41] Pedai T, Hadisutrisno B and Priyatmojo A. 2015.Utilization of arbuscular micorrhizal fungi to control fusarium wilt of tomatoes. J. Perlind. Tan.Indon. 19: 89-93.

[42] Pfeffer PE, Douds DD, Bécard JrG and Shachar-Hill Y. 1999. Carbon uptake and the metabolism and transport of lipids in an arbuscular mycorrhiza. Plant Physiol. 120: 587 - 598.

[43] Poovarasan S, Mohandas S, Paneerselvam P, Saritha B and, Ajay KM. 2013. Mycorrhizae colonizing actinomycetes promote plant growth and control bacterial blight disease of pomegranate (Punica granatum L cv Bhagwa). Crop Protection 53: 175-181.

[44] Putri D, Nasir N dan Alamsyah F. 2016. Pengaruh Fungi Mikoriza Arbuskula terhadap penyakit jamur akar putih (Rigidoporus microporus) pada bibit tanaman karet (Hevea brasiliensis). Pros Sem Nas Masy Biodiv Indon 2: 7-11.

[45] Remy, W., Taylor T. N, Hass H and Kerp H. 1994. Fourhundred-million-year-old vesicular arbuscular mycorrhizae. Proc.Natl.Acad.Sci.USA91: 11841-11843,

[46] Rias RR, Rini MV dan Yelli F. 2014. Seleksi lima isolat fungi mikoriza arbuskular untuk pembibitan kelapa sawit (Elaeis guineensis Jacq,) pada dua dosis pupuk NPK. J. Pen. Pert. Terapan 15: 24-32.

[47] Ristiyanti, Yusran dan Rahmawati. 2014. Pengaruh beberapa spesies fungi mikoriza arbuskular pada media tanah dengan ph berbeda terhadap pertumbuhan semai kemiri (Aleurites moluccana (1,) Willd). Warta Rimba 2: 117-124. 
[48] Rozy F, Liestiany dan Maftuhah. 2004. Kemampuan mikoriza mengendalikan serangan Rhizoctonia solani Kuhn pada kedelai. Agroscientiae 11: 91-98.

[49] Ruiz-Lozano JM, Azcon R, and Gomez M. 1995. Effects of Arbuscular-Mycorrhizal Glomus Species on Drought Tolerance: Physiological and Nutritional Plant Responses. Appl. Environ. Microbiol. 61: 456460.

[50] Ruzicka D, Chamala S, Barrios-Masias FH, Martin F, Smith S, Jackson LE, Barbazuk WB and Schachtman DP. 2013. Inside arbuscular mycorrhizal roots-molecular probes to understand the symbiosis. The Plant Genome 6: 1-13.

[51] Salami AO and Olawole OI. 2011. Ditrophic interaction between Glomus mosseae and Phytophthora infestans in jute mallow (Corchorus olitorius) seedlings at different ages. J. Agric. Sci. Env. 11: 1-15.

[52] Saleh N dan WidodoY . 2007. Profil dan peluang pengembangan ubi kayudi indonesia Bul. Palawija No. 14: 69-78.

[53] Sankaralingam S, Harinathan B, Palpperumal S, Kathiresan D, Shankar T and Prabhu D. 2016. Effect of arbuscular mycorrhizal fungi on the growth and development of Carica papaya L, Inter. J. Innov in Agric. Sci. 1:1-10

[54] Sharma MP, Gaur A, Bhatia NP, Adholeya A. 1996. Growth responses and dependence of Acacia nilotica var. cupriciformis on the indigenous arbuscular mycorrhizal consortium of a marginal wasteland soil. Mycorrhiza 6: 441-446

[55] Soedarjo M and Habte M. 1993. Vesicular-arbuscularmycorrhizal effectiveness in an acid soil amended with fresh organic matter. Plant and Soil 149:197-204.

[56] Soedarjo M and Habte M. 1995. Mycorrhizal and non-mycrrhizal host growth in response to changes in $\mathrm{pH}$ and $\mathrm{P}$ concentration in a manganiferous oxisol, Mycorrhizae 5: 337-345.

[57] Solaiman MDZ and Saito MI. 1997.Use of sugars by intraradical hyphae of arbuscular mycorrhizal fungi revealed by radiorespiroraetry.New Phytol. 136: 533-538.

[58] Sridevi S and Ramakrishnan K. 2013.Effect of inoculation with NPK fertilizer and arbuscular on growth and yield of cassava. Inter. J. Dev. Res. 3:046-050.

[59] Suswati, Nasir dan Azwana. 2013. Peningkatan ketahanan tanaman pisang barangan terhadap blood disease bacterium (bdb) dengan aplikasi fungi mikoriza arbuskular indigenus. J. HPT Tropika 13: 96 104 ,

[60] Tawaraya K. 2003. Arbuscular mycorrhizal dependency of different plant species and cultivars.Soil Sci. Plant Nutl. 49: 655-668.

[61] Tong-jian X, Qing-song Y, Guo-hua X and Qi-rong S. 2010.Effect of inoculation with arbuscular mycorrhizal fungus on nitrogen and phosphorus utilization in upland rice-mungbean intercropping system. Agric. Sci. in China 9: 528-535.

[62] Wargiono J. 2003. Pemupukan NPK dan sistem tanam ubikayu padatanah Ultisol Lampung.Pen.Pert.Tan. Pangan 22: 114-120.

[63] Wu Q-S, Zoua Y-N and Heb XH. 2011. Differences of hyphal and soil phosphatase activities in droughtstressed mycorrhizal trifoliate orange (Poncirus trifoliata) seedlings. Scientia Horticulturae 129: 294-298

[64] Yaseen T, Burni T and Hussain F. 2011.Effect of arbuscular mycorrhizal inoculation on nutrient uptake, growth and productivity of cowpea (Vigna unguiculata) varieties.Afric. J. Biotechnol. 10: 8593-8598.

[65] Yaqub, F and Shahzad S. 2005.Pathogencity of Sclerotium rolfsii on different crops and effect of inoculum density on colonization of mungbean and sunflower roots. Pak. J. Bot. 37: 175-180.

[66] YoshibaY, Kiyosue T, Nakashima K, Yamaguchi-Shinozaki K and Shinozakj. 1997. Regulation of levels of proline as an osmolyte in plants under water stress. Plant Cell Physiol. 38: 1095-1102

[67] Zachée A, Bekolo N, Bime, Dooh Ng, Yalen M and Godswill N. 2008. Effect of mycorrhizal inoculum and urea fertilizer on diseases development and yield of groundnut crops (Arachis hypogaea L.). Afric.J. Biotechnol. 7: 2823-2827.

Citation: Muchdar Soedarjo, "Mutualistic Symbiosis between Arbuscular Visicular Mycorrhizal Fungi with Cassava Plant (Manihot esculenta Crantz)" International Journal of Research Studies in Agricultural Sciences (IJRSAS), 2019; 5(11), pp. 8-17, http://dx.doi.org/10.20431/2454-6224.0511002

Copyright: (C) 2019 Authors. This is an open-access article distributed under the terms of the Creative Commons Attribution License, which permits unrestricted use, distribution, and reproduction in any medium, provided the original author and source are credited. 